Journal of Information Systems Engineering \& Management, 2:1 (2017), 3

ISSN: 2468-4376

\title{
Mobile Health, a Key Factor Enhancing Disease Prevention Campaigns: Looking for Evidences in Kidney Disease Prevention
}

\author{
Nicole Roque Matias ${ }^{1 *}$, Maria José Sousa ${ }^{1}$ \\ ${ }^{1}$ Universidade Europeia, PORTUGAL \\ *Corresponding Author: nicolermatias@gmail.com \\ Citation: Author and Author. (2017) Mobile Health, a Key Factor Enhancing Disease Prevention \\ Campaigns: Looking for Evidences in Kidney Disease Prevention, Journal of Information Systems Engineering \& \\ Management, 2:1 (2017), 3.
}

doi: http://dx.doi.org/10.20897/jisem.201703

Published: January 5, 2017

\begin{abstract}
Background: Progressive chronic kidney disease (CKD) failure and kidney diseases are increasing at an alarming rate all over the world. However, despite the remarkable advance in health technology, where it has become possible to successfully screen patients and predict kidney progression, a large portion of the world population is still unaware of their disease and risk exposure. Mobile Health (mHealth) solutions associated with health campaigns and programs proved to be an effective mean to enhance awareness and behaviour change at individual and social level.

Objective: The aim of this survey was to present the results of an environmental scan of what has been happening in the field of kidney disease prevention campaigns in recent years, with a focus on the use of mobile health as a tool to enhance the campaign's effects on targeting people and change their behaviour.

Methodology: It was conducted a systematic and comprehensive review, combining experimental studies with theoretical perspectives, to look for evidence regarding the evaluation of kidney disease prevention campaigns. The databases consulted for the present survey were: MEDLINE, PubMed, Google Scholar, PsycINFO, SAGE Journals Online, and Web of Science among other sources, for an analysis period from January 2000 to June 2016.

Results: Concerning the 14 analyzed examples with impact on kidney disease prevention campaign evaluation, two main campaigns were referred: The World Kidney Day (WKD) campaign, and the Kidney Early Evaluation Program (KEEP). The indicators used in this analisys were in most cases comparable regarding the campaign messages, objectives and interventions tools, although em both cases the use of $\mathrm{mHealth}$ or other technologies is residually comparing to other diseases prevention campaigns or programs. Conclusions: This review pointed to the inexistence of behavioural change evidence as a target of the kidney disease prevention campaigns and their evaluation. General deficiencies concerning the use of technology to target and engage populations and lack of theory-based interventions, might have contributed for these results. This study highlights the need for reviewing the campaigns design and methodologies, redesigning strategies all over the campaign processes and the need of developing more tools and indicators, based on technology intervention for population's engagement on campaigns regarding kidney disease prevention.
\end{abstract}

Keywords: mHealth, behaviour change, disease prevention, kidney disease and health campaigns

\section{INTRODUCTION}

The idea of chronic disease has been modified throughout time. After the 1960s this concept assumed that bodies are intrinsically sick due to genes, traumas or life-styles, on the other, health, for the chronically ill individual 
is not a condition of their existence, in which they are never healthy, but rather something located in time, both relative and experiential (Dumit 2012). It is within this framework that disease prevention campaigns multiply their scope and tools in the last years, each time more enhanced and supported by interactive technologies. Under these cross relations between technologies and prevention campaigns, we are looking for evidences in behaviour change, regarding chronic kidney disease prevention.

Chronicity as a condition is reaching significant proportions and costs all over the world (World Health Organization 2013), under these perspective non-communicable diseases (NCDs) are the globally leading cause of death, killing more people each year than all the other combined causes. At present, people spend less than $0.1 \%$ of their time on disease prevention and healthy behaviour guidance. If nothing changes until 2030, the cost of chronic disease throughout the world will reach 47 trillion dollars (National Center for Chronic Disease Prevention 2009), (Johnson et al. 2014). The WHO has considered, since 2011, kidney disease as one of the items listed among the main concerns of NCD's intervention. For many patients, CKD is associated with substantial mortality and morbidity, being diabetes and hypertension the two major risk factors for this disease (National Center for Chronic Disease Prevention 2009). Earlier recognition of chronic disease (CKD) could slow progression, prevent complications and reduce cardiovascular-related outcomes. Prevention programs and campaigns play an important role in these interventions (European Center for Disease Prevention and Control 2007), at the same time we are living in a society where technologies assume an increasingly important role in structural behaviour changes. The way in which technologies influences behaviour and the creation of new social interaction dynamics, lead to the incorporation of social media and mHealth in health campaigns and programs, as a preferential platform for prevention (Castelnuovo et al. 2015), (Wildevuur et al. 2015). Throughout this process technology is changing every day our interactions and communication process (Fernández-Luque \& Bau 2015). The most popular communication channels in recent decades have totally changed. At present, mobile networks have more than 7 billion subscribers worldwide; predictions for 2020 indicate 9.2 billion mobile devices subscriptions. Smartphones lead this process and it is estimated that in 2020 they will be responsible for approximately $80 \%$ of all mobile data traffic (SNS Research 2014), (Research and Markets 2015). The proximity of these devices to their users gives them a privileged place in prevention programs and campaigns implementation, as a tool for behaviour change.

\section{METHODOLOGY}

This literature review has as purpose to answer the following questions: What has been happening regarding the use of mHealth solutions with focus on kidney disease prevention campaigns? Which technologies are being used in kidney disease campaigns? What opportunities merge with the use of technologies in kidney disease prevention campaigns?

Literature was identified by conducting databases searches for published academic literature: MEDLINE, Google Scholar, PsycINFO, SAGE Journals Online and Web of Science. In addition, two journals were reviewed for relevant articles: Journal of Health Communication and two specific medical journals. Other documents were through general Internet searches using Google to to identify additional relevant literature, such as reports or technical documents (grey literature) that responded to the defined inclusion criteria. Searches of the following websites were also undertaken: European Centre for Disease Prevention and Control, World Health Organization and the US Centers for Disease Control and Prevention. Publications were initially screened for potential inclusion based on simultaneous review of title and abstract. Information including objectives, campaign tools, behaviour change evidence, study sample characteristics, outcomes measured, and results reported were extracted using a word table (Table 1 - Appendix A).

The terms used in the literature searches included but were not restricted to:

- "Health communication" and "Health Campaigns"

- "Disease Prevention" and "Health Promotion"

- "Disease Prevention Programs" and "Kidney disease campaigns"

- "Chronic Disease" and "Kidney chronic disease"

- "mHealth" and "Social media" and "digital technologies"

- "Behaviour Change" and "mHealth"

Noted search terms were also examined in conjunction with terms identifying health behaviours promoted though awareness and prevention commonly promoted though the use of mass mediated-appeals and screenings. In the MEDLINE database, the following medical subject's headings were also utilized to identify articles: noncommunicable chronic disease, kidney disease campaign, kidney disease awareness, kidney evaluation program and patient awareness of CKD. According to these searches criteria were found 275 references of which 87 related to health communication campaigns, 66 related to behaviour change interventions that use technologies, 91 related to chronic disease prevention campaigns and 18 were examples of campaign evaluation carried in the field of kidney disease. In addition were found in two specific medical journals (Seminars of Nephrology and Nephrology 
Dialysis Transplantation) 8 exploratory literature reviews and 5 examples of kidney disease campaign evaluation. After reviewing the articles, additional materials were found using their bibliographies, providing additional insights with a total of 14 examples of campaigns on kidney disease prevention (Table 1 - Appendix A).

The review was restricted to English language documents. The search was limited to papers published between January 2000 and January 2016.

\section{mHealth, A GAME CHANGER IN HEALTH INTERVENTIONS}

Robert Istepanian, engineer, and professor, defined the term mHealth (mobile health) as: "emerging mobile communications and network technologies for healthcare" (Istepanian et al. 2006:3). The Global Observatory for eHealth defines mHealth as a public and private health practice supported by mobile communication devices, such as mobile phones, tablets and PDA's (Kay et al. 2011). mHealth operates on the premise that the integration of technologies in the health sector has huge potential regarding promotion and better communication on healthcare (Chetley et al. 2006), (World Health Organization 2006). From this perspective, the concept of mHealth, defined by the World Health Organization as "The use of mobile and wireless technologies to support the achievement of health objectives" (Kay et al. 2011:1), is shown as one of the game changes with great intervention potential in the field of health, due to higher market permeability, interaction capacity and user accessibility (Fernández-Luque \& Bau 2015). The definition of game changer in healthcare as an element or factor that changes an existing situation or activity in a significant way, though innovations considered disruptive due to their innovative capacity, capable of changing future interactions in the health sector (Johnson et al. 2014), (Greenspun \& Coughlin 2012), (World Health Organization 2014). The mobile penetration in developed countries area almost $100 \%$ and the developing countries follow the same trend (Delloit Center for Health Solutions 2015), which gives mHealth solutions an enormous potential as a game changer for global health (Ernest \& Young 2012). The Economist Intelligence Unit cited mHealth as a catalyser, able to improve access to care in emerging markets and transform the developed world's costly healthcare burden into less expensive, prevention-based and patient-focused systems (The Economist Intelligence Unit 2014), (Denninson et al. 2013). The target group of mHealth usually appears classified into healthy people, hospital patients and chronically ill individuals (Georgsson \& Staggers 2016), referred to four domains: wellness and prevention; diagnosis; treatment and monitoring; and stronger healthcare systems (Delloit Center for Health Solutions 2015), (Miyamoto et al. 2016). In this literature review the domain that we intent to study are focused on wellness and prevention, with special incidence in chronic disease prevention. Under this scope mHealth solutions are appointed as a transformational tool in health care regarding peoples behaviours, namely in areas such as patient's engagement improvement, contributing to patient understanding of their health, and facilitating the tracking and management of chronic illnesses (Wets 2012).

\section{DEFINITIONS AND CONCEPTS AROUND HEALTH COMMUNICATION CAMPAIGNS}

Definitions of health communications Campaigns are referred in literature as unclear and ambiguous. Previous researchers have commented on the frequent ambiguity in the use of labels such as: campaign, communication campaign or program, awareness campaign, mass media campaign and intervention (Fox et al. 2014).

Lamb defined campaign in 1997 as ' (...) an organized effort to bring public pressure to bear on institutions and individuals so as to influence their actions.' (Lamb 2010). Two broad types of campaigns can be difference: (1) campaigns that intents for institutional and policy change, and (2) campaigns aiming for change in individual behaviour and social norms and attitudes. We can also find in literature about public communication campaigns this distinction based on the primary goals of these campaigns: individual behaviour changes versus public will and political change (e.g., Dungan-Seaver, 1999; Henry \& Rivera, 1998 cited in Coffman 2003). A public will campaign pursuits to legitimize or raise the importance of a social problem in the public as the motivation for policy action or change (Henry \& Rivera, 1998, cit. in Coffman 2003). It focuses more on the public responsibility of doing something that will create the environment needed to support behaviour change than on the individual who is performing the behaviour.

Awareness-raising or prevention campaigns, are under the umbrella of health communication campaigns, and fit under both types as their aim is to influence individual's behaviour regarding their health and life style, disease prevention and also be a means of attracting attention and generating public support - public awareness is an important element whether seeking individual behaviour, policy change or both (Coffman 2003) (Lamb 2010). Regarding health communication campaign approach, Bauman in 2000 described media campaigns as a set of organized and purposive activities, separated, although complementary to the use of media for public health advocacy, which uses a variety of media channels to inform, persuade or motivate populations (Bauman 2002). 
Hornik referred the importance of mass media campaigns to promote healthy behaviours and discourage unhealthy behaviours as a major tool for public health practitioners in their efforts to improve the public health (Hornick 2002). In the other hand, Flynn and colleagues reinforces that what distinguishes mass media campaigns is related to simply directing standard messages to large populations simultaneously (Flynn et al. 2009). Although health communication campaigns, as a part of public communication campaigns definition, have different approaches, simultaneously they share many characteristics, as outlined by Rogers \& Storey (cited in Atkin \& Rice 2012:4). These include their general aim to produce specific outcomes, usually a change in behaviour, in a significatively large group of individuals within a pre-determined time frame and through a specified series of communication activities (Atkin \& Rice 2012).

All these definitions, many times used to describe the same purpose, have in their focus on similar results, trying to influence what people think, think about, and do (Schiavo 2013).

\section{PREVENTING CHRONIC DISEASE THROUGH HEALTH COMMUNICATION CAMPAIGNS}

Health Organizations studies report that a major reduction in the burden of NCDs will come from populationwide and effective interventions. There is still a lack of wide scale interventions, commonly associated with inadequate political commitment, insufficient engagement of non-health sectors, lack of resources and limited engagement of key stakeholders (World Health Organization 2013). Preventing is fundamental, attending that many NCD-related health-care interventions are high cost effective, especially compared to costly procedures, which may be necessary when detection and treatment are late and the patient reaches advanced stages of the disease (Tunstall-Pedoe 2006). Among the Global NCD Action Plan 2013-2020 objectives, more monitoring about trends and determinants of NCDs, progress in disease prevention and evaluation impacts of health communication interventions are needed to develop effective and affordable interventions (World Health Organization 2013). Health communication, which is defined by Center for Disease Control and Prevention (CDC) and the National Cancer Institute, as "The study and use of communication strategies to inform and influence individual and community decisions that enhance health" (Doyle 2012, cited in Sixsmith 2014:7). Health communication campaigns include their general aim to produce specific outcomes, usually a change in behaviour, in a significatively large group of individuals within a pre-determined time frame and through a specified series of communication activities (Atkin \& Rice 2012). Communication includes public relations, entertainment education for behaviour change, media advocacy tool to achieve policy level change, among others (Coffman 2003). Health communication is accountable to the people whose health and social outcomes public health measures seek to improve, to the lives that are possible to spare through prevention and system-changing strategies, to the health authorities and to society, among other key stakeholders (Schiavo 2013).

\section{SOCIAL AND BEHAVIOUR CHANGE THEORIES IN THE SCOPE mHealth PREVENTION PROGRAMS}

Social change is sustainable only when different levels of society are affected by the health communication intervention. Targeting individual's behaviour is not enough to achieve behavioural change (Shiavo 2013), (Fawcett et al. 2000). Social and organizational outcomes are the result of gradual behavioural changes by the stakeholders, communities, policymakers, and professionals from different sectors and levels of society; behavioural outcomes are still a key measurement (Figure 1).

The most successful mHealth programs and initiatives are based on an understanding of health behaviours and the context in which they occur (Fawcett et al. 2000). Therefore, interventions to improve health behaviour can be best designed with an understanding of relevant theories of behaviour change and the ability to use them skilfully. The science and art of using health behaviour theories reflect an amalgamation of approaches, methods, and strategies from social and health sciences, to medicine, as this literature review shows.

Theories can address factors on the individual level (Badura, Clark, Janevic cited in Riekert et al. 2013:104) or on multi-level or community based models (Fitzgibbon, Karg and Tussing-Humphreys cited in Riekert et al. 2013:13). The individual theories addresses: social cognitive theory, self-regulation model, health belief model, and theory of planned action, transtheoretical model and relapse prevention model. On the other hand, the Community Based Models addresses how socio-ecological models that address the multiple levels on influence on behaviour can be used for developing interventions that support healthy life-styles. Another approach is the Healthy System Models (Glasgow \& Stange cited in Riekert et al. 2013:105) that includes the Chronic Care Model, the practice change, complex adapter system models and the RE-AIM/prims Models. 


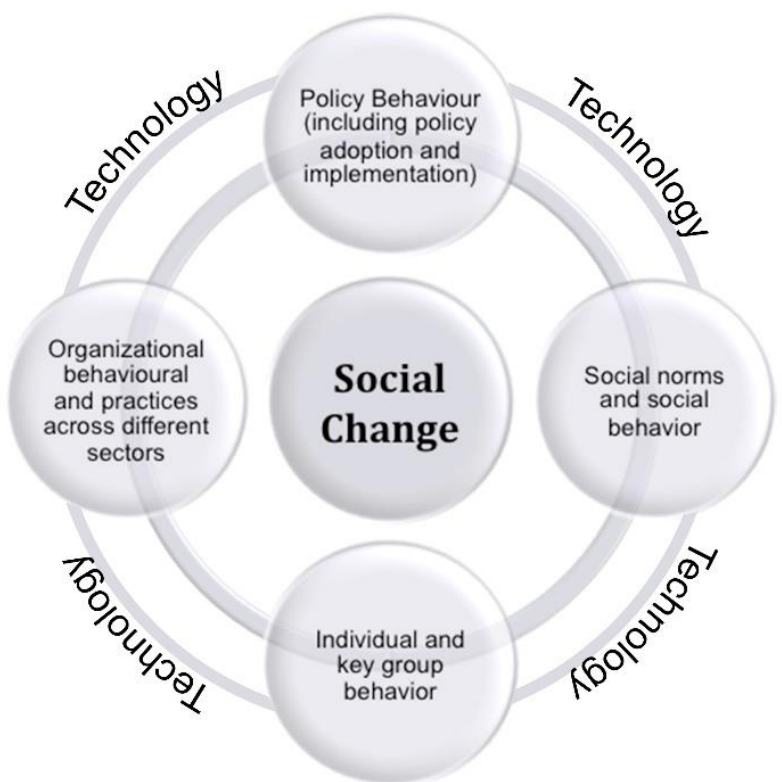

Figure 1. Social Change and Behaviour Indicators (Adapted from Shiavo, 2013)

Theories can guide researches to understand why people do or do not practice health-promoting behaviours; to help identifying what information is needed to design an effective intervention strategy, and to provide knowledge into how to design a program/campaign, so it is successful (Hornik 2002), (Riekert 2013). Accordingly to recent literature review under this scope the most referred theories that support mHealth intervention programs on behaviour change, regarding noncomunicable chronic diseases prevention, were the Social Cognitive Theory (SCT), the Thanstheoretical Model (TTM) and the Chronic Care Model (CCM) (Matias \& Sousa 2016). Covering a range of behavioural topics, most of them suggest chronic disease prevention areas like primary care, physical exercise, healthier life-style, diabetes and obesity prevention. The conclusions pointed that interventions based on theory or explicitly described theoretical constructs were effective to influence change behaviour through mHealth, where the Social Cognitive Theory appears to be the most used theory for behaviour change interventions programs. However, when it comes to evidences, mobile phone messaging for preventive health care (VodopivecJamsek et al. 2012) seems to have a lack of evidence regarding long-term benefits for preventive health care. On the other hand mHealth is referred has having the potential, but, however, its effectiveness must be proven in well design and rigorously conducted clinical trials (Redfern at al. 2014), (Dale et al. 2015). The increasing of information technology tools such as the internet, wireless technology, and other digital support have enlarged the range of theory-based strategies available for effective behaviour change in health care and community settings (Dennisson et al. 2013). Regarding the main limitations referred in these studies, behavioural interventions should be sensitive to audience and contextual factors, and recognize that most behaviour change is incremental and that maintenance of change usually requires continued and focused efforts, attending in a stronger direction the communities in which people live and work (Vodopivec-Jamsek 2012), (Sallis et al. 2008). However, few researches refers the use of community based models for this interventions or programs, the importance of targeting at interpersonal, organizational and environmental level, is becoming each time more evident in health behaviour change matters (Sallis et al. 2008), (Dale et al. 2015), (Matias \& Sousa 2016).

\section{ARE DISEASE PREVENTION CAMPAIGNS USING mHealth SOLUTIONS FOR INTERVENTIONS?}

The use of mHealth solutions, through social media, Facebook, online communities, online programs games has been advanced as having the capacity to influence voluntary behaviours, such as those routinely targeted by health communication campaigns (Ryz et al, 2015), (Gase et al. 2015).

At the same time, it presents to be a relatively inexpensive way to deliver health promotion messaging, proving the potential of these solutions for health promotion, disease prevention and behaviour change. Effective targeting and deployment of these interventions requires a solid understanding of what to measure and how to do it. For instance metrics will need to capture the interactivity of Web 2.0 technology as well as behavioural responses to the new media that are not yet well understood. Measuring meaningful engagement and privacy issues are other problem for those using online social media for health promotion (Korda \& Itani 2013), (Hornik \& Yanovitzky 2003). 
Given the high availability and low cost of online technologies, the stage may be set for increased public health campaigns that blend online interpersonal systems with mass-media outreach. Such a combination of approaches could help individuals, improving the quality of their lives and at a state level, contribute to healthier societies (Ryz et al. 2015).

\section{Kidney Disease Campaigns}

Until recently, the WHO consensus statement on NCDs (noncommunicable diseases) did not include kidney disease. In 2011 the Political Declaration on NCDs from the United Nations Summit mentioned for the first-time kidney disease under its listed items (Ramo et al. 2015), (Jha et al. 2013). Increasing education and awareness about renal diseases in general is framed with the objectives of the WHO to reduce mortality from NCD in a10-year time frame, appealing to initiatives, focused life style changes (including tobacco reduction, salt intake control, dietary energy control, and alcohol intake reduction) and effective interventions, including blood pressure, cholesterol and glycaemia control (Levey 2003), (Nasri et al. 2015).

A deep review research of recent years concerning kidney disease prevention campaigns are described in Table 1 (Appendix A). From this panel analysis, we can enhance two main campaigns regarding kidney disease prevention. The World Kidney Day campaign (WKD) that started in 1996, and the Kidney Early Evaluation Program (KEEP) that stared in 2000. These campaigns have been developed with the main purpose of raising awareness about the importance of kidneys, reduce the frequency and impact of kidney disease, increase the public understanding of CKD prevention and promote access to kidney disease-screening programs to detect CKD. The WKD is an annual campaign, sponsored jointly by the International Society of Nephrology (ISN) and the International Federation of Kidney Foundations (IFKF), and is an effort to inform the general public and policymakers about prevention and consequences of kidney disease. The primary goal for WKD is to attract attention to kidney disease as a global pandemic, with its associated morbidity and mortality, resulted from the enlargement of cardiovascular risk. The general message of the world kidney day (WKD) is a concerted knowledge '(...) against the illnesses that lead to end-stage kidney failure, through better education, improved economic opportunity, increasing community outreach and access to protective medicine for individuals at the highest risk.' (National Kidney Foundation 2016). Over the last years, more than 60 countries participated in this campaign, through the promotion of health screening events, public lectures, media and web conferences, political activities, and other efforts to better inform children, families, school teachers, care physicians, allied health professionals and population in general, as well as government health officials about the raising dimension of kidney disease (Khalil et al. 2014), (Vassaloti et al. 2010). The National Kidney Foundation (NKF) founded the Kidney Early Evaluation Program (KEEP) in 2000, and under the scope of a public health program, focused on offering surveillance and early detection of CKD (Jurkovitz et al. 2008). KEEP is a free community-based, kidney diseasescreening program, designed to raise awareness about kidney disease among high-risk individuals. Among many initiatives KEEP provide free testing and educational information to help prevent or delay kidney disease and its complications. Early CKD detection allows promoting follow-up evaluation with clinicians to ultimately improving outcomes. KEEP aims the early detection of kidney disease among individuals with diabetes mellitus, arterial hypertension, or a family history of diabetes, hypertension, or chronic kidney disease (Obrador et al. 2010), (Levey et al. 2003).

Interventions and campaigns regarding kidney disease prevention appears to use as main tools to promote and engage populations the use of screenings, brochures, TV and Radio advertising and printed materials. Just a few of them used web based advertisement or social media resources to promote the campaign and target populations (Nasri et al. 2015), (Ryz et al. 2015), Roomizadeh et al. 2014), (Ingelfinger et al. 2016). The use of online surveys also is residual to have feedback on campaigns. Among many possibilities around mHealth technologies when it refers to chronic kidney disease, there is a poor evidence and use of technologies when compared with other chronic diseases prevention campaigns (Redfern et al. 2014), (Dale et al. 2015), (Matias \& Sousa 2016).

\section{EVIDENCES AND CONCLUSIONS}

Health communication campaigns aims to influence people's behaviour regarding their health and life style (Coffman 2003), (Hornik 2002), (Flynn at al. 2009). More monitoring about trends and determinants, of kidney disease prevention and evaluation impacts of health communication interventions, are needed to develop effective and affordable interventions (Sixsmith et al. 2014). Chronic kidney disease is increasing at an alarming rate. Despite all the prevention campaigns, possibilities of screening CKD in populations and kidney progression prediction, a large portion of the world populations is still unaware of their diseases and their risk exposure. Chronic kidney disease was recognized as one of the NCDs priority listed items in 2011 (Jha et al. 2013). The increasingly number of initiatives take worldwide is growing under the umbrella of kidney disease prevention campaigns, reflecting the efforts taken to increase education and awareness of $\mathrm{CKD}$, the significance of improving earlier detection and the 
need of more focusing on changes in life-style, including tobacco use reduction, salt intake control and alcohol intake reduction (Levey et al. 2003), (Nasri et al. 2015). Two main campaigns results emerge from this research, the World Kidney Day (WKD) and the Kidney Early Evaluation Program KEEP. The indicators used in these campaigns were in most cases comparable regarding the campaign messages, objectives and intervention tools, although WKD is more focused on exploring knowledge about CKD and prevention messages, with a mass media strong support and KEEP with a main focus on screening activities. One of the WKD limitations could be the focus on tools of media channels used to alert people, which are not sufficient to effectively educate public (Ingelfinger et al. 2016), (Figueroa et al. 2002).

The failure to find effects and behaviour change evidences could reflect a true failure of the campaign because of poorly chosen behavioural objectives, poorly designed messages, or, quite often, because of insufficient exposure to campaign messages (Mastroianni-Kirsztajn et al. 2002), (Ryz et 1. 2015), (Ingelfinger et al. 2016). This research highlights that there is a lack and at the same time an improvement opportunity regarding behaviour change evidence on campaign evaluation for kidney disease prevention. None of the selected studies for this analysis (Table 1 - Appendix A) evidences behaviour change neither in objectives definitions nor campaign outcomes. As part of all kinds of evaluation efforts, it's important to enhance that behavioural and social change occur only over time. Only long-term efforts can generate sustainable behavioural results, which may also lead to social change (Figueroa 2002). Just a few interventions and campaigns regarding kidney disease prevention used web based advertisement or social media resources to promote the campaign and target populations (Nasri 2015), (Hornik \& Yanovitzky 2003), (Ryz et al. 2015), (de Lima et al. 202). The use of online surveys also is residual to have feedback on campaigns. Among many possibilities around mHealth technologies when it refers to chronic kidney disease, there is a poor evidence and use of technologies when compared with other chronic diseases prevention campaigns (Dale et al. 2015), (Redfern et al. 2014).

Also, more research is needed to create solid evidence regarding the use of mHealth, as influence on change behaviour and kidney disease prevention campaigns effects improvement. Theory and research suggest that the most effective disease prevention campaigns are those that use multiple strategies to influence behaviour (Mastroianni et al. 2010) (Dale et al. 2015), (Atkins \& Zimmet 2010) aim to achieve multiple goals of awareness, improve people's engagement and use technology as a communication basis. Goal setting and monitoring are crucial elements for successful interventions. The incrinsigly pontential and offer of information technology tools such as the internet, wireless technology, and personal digital assistants allows campaigns to improve individual's engagement and behaviour change (Shiavo 2013), (Fawcet et al. 2000).

As conclusion, we can reinforce that there is an urgent need for evidence-based campaigns that can positively influence knowledge of CKD (Chin et al. 2010), (Akuse et al. 2012), (Jurkovitz et al. 2008), (Koshy et al. 2009). This research study sought to find links between behaviour change, kidney disease prevention, and technology but these reseachers point that there is a lack of studies that connect these areas. In general, the objectives of the analysed campaigns were focused only on awareness mainly with pours technology resources.

The outlook of health promotion and its reach are rapidly changing. Initiatives using $\mathrm{mHealth}$ and digitalized solutions to enhance disease prevention initiatives may be viewed as something that is already in it's beginning. $\mathrm{mHealth}$ technologies offer interesting possibilities for health promotion and disease prevention interventions and the exponential entry of commercial apps, self-tracking devices, platfoms and smart objects and environments into health promotion are an increasingly reality across all ages and social-economic targets. To date there is very modest evidence that interventions incorporating $\mathrm{mHealth}$ may be effective regarding kidney disease prevention; however, this field of research is in its infancy.

\section{REFERENCES}

Akuse, R., Ibrahim, A., Bugaje, M., Yakubu, A., Raji, J., Ebene, E., Eno, H., Abdukareem, H., Ochube, K., Gabaolu, S. and Daniel, L. (2012). World Kidney Day - Don't Forget the Children. The Internet Journal of Nephrology, 6(2).

Atkin, C.K. and Rice, R.E. (2012). Theory and principles of public communication campaigns. In C.K. Atkin and R.E. Rice, ed., Public communication campaigns (pp. 3-20).

Atkins, R.C. and Zimmet, P. (2010). Diabetic kidney disease: Act now or pay later-world kidney day, 11 march 2010. Therapeutic Apheresis and Dialysis, 14(1), pp. 1-4.

Bauman A. (2000). Precepts and principles of mass media campaign evaluation in Australia. Health Promotion Journal of Australia: Official Journal of Australian Association of Health Promotion Professionals, 10(2), pp. 89-92.

Behavioural and Social Changes Research (n.d.). Available at: http://www.esourceresearch.org/Default.aspx?TabId=746. (Accessed 15 March 2016).

Castelnuovo, G., Pietrabissa, G., Manzoni, G.M., Corti, S., Ceccarini, M., Borrello, Giusti, E., Novelli, M., Cattivelli, R., Middleton, N., Simpson, S. and Molinari, E. (2015). Chronic care management of globesity: Promoting 
healthier lifestyles in traditional and mHealth based settings. Frontiers in psychology, 6, pp. 1557. DOI: 10.3389/fpsyg.2015.01557

Chetley, A., Davies, J., Trude, B., McConnell, H. and Ramirez, R. (2006). Improving health connecting people: The role of ICTs in the health sector of developing countries. Available: https://www.infodev.org/infodevfiles/resource/InfodevDocuments_84.pdf (Acessed 5 March 2016).

Chin, H.J., Ahn, J.M., Na, K.Y., Chae, D.W., Lee, T.W., Heo, N.J. and Kim, S. (2010). The effect of the World Kidney Day campaign on the awareness of chronic kidney disease and the status of risk factors for cardiovascular disease and renal progression. Nephrology Dialysis Transplantation, 25(2), pp. 413419. DOI:10.1093/ndt/gfp512

Coffman, J. (2003). Lessons in evaluating communications campaigns: Five case studies. Harvard Family Research Project. Available at: http://citeseerx.ist.psu.edu/viewdoc/download?doi=10.1.1.490.8914\&rep=rep1\&type=pdf. (Acessed 2 June 2016).

Dale, L.P., Whittaker, R., Jiang, Y., Stewart, R., Rolleston, A. and Maddison, R. (2015). Text message and internet support for coronary heart disease self-management: results from the Text4Heart randomized controlled trial. Journal of medical Internet research, 17(10), e237. DOI:10.2196/jmir.4944

de Lima, A.O., Kesrouani, S., Gomes, R.A., Cruz, J. and Mastroianni-Kirsztajn, G. (2012). Population screening for chronic kidney disease: a survey involving 38721 Brazilians. Nephrology Dialysis Transplantation, gfs063. DOI: $10.1093 / \mathrm{ndt} / \mathrm{gfs} 063$

Delloit Center for Health Solutions (2015). Connect health. How digital technology is transforming health and social care. Available at: http://www2.deloitte.com/content/dam/Deloitte/uk/Documents/life-sciences-healthcare/deloitte-uk-connected-health.pdf. (Accessed 10 April 2016)

Dennison, L., Morrison, L., Conway, G. and Yardley, L. (2013). Opportunities and challenges for smartphone applications in supporting health behavior change: qualitative study. Journal of Medical Internet Research, 15(4), e86. DOI: $10.2196 /$ jmir.2583.

Dumit, J. (2012). Drugs for Life: Growing Health through Facts and Pharmaceuticals. Durham: Duke University Press.

Ernest \& Young (2012). mHealth Mobile technology poised to enable a new era in health care. Available at: http://www.ictliteracy.info/rf.pdf/mHealth\%20Report_Final.pdf (Accessed 10 April 2016)

European Centre for Disease Prevention and Control (2007). ECDC strategic multi-annual programme 20072013. Public health activities, disease-specific programmes and multilateral partnerships. Available from: http://ecdc.europa.eu/en/aboutus/key\%20documents/07-13_kd_strategic_multiannual_programme.pdf (Acessed 6 April 2016).

Fawcett, S.B., Francisco, V.T., Schultz, J.A., Berkowitz, B., Wolff, T.J. and Nagy, G. (2000). The Community Tool Box: A Web-based resource for building healthier communities. Public health reports, 115(2-3), 274.

Feehally, J. (2012). Chronic kidney disease: Health burden of kidney disease recognized by UN. Nature Reviews Nephrology, 8(1), pp. 12-13.

Fernández-Luque, L. and Bau, T. (2015). Health and Social Media: Perfect Storm of Information. Healthcare Informatics Research, 21(2), pp. 67-73. DOI:10.4258/hir.2015.21.2.67

Figueroa, M.E., Kincaid, D.L., Rani, M. and Lewis, G. (2002). Communication for social change: An integrated model for measuring the process and its outcomes.

Flynn B.S., Worden J.K. and Bunn J.Y. (2009). Comparison of research designs for two controlled trials of mass media interventions. Communication Methods and Measures, 3(1-2), pp. 12-28.

Fox, K.A., Sixsmith, J., Doyle, P. and Barry, M.M. (2014). A literature review on health communication campaign evaluation with regard to the prevention and control of communicable diseases in Europe, Stockholm: ECDC. Available at: http://ecdc.europa.eu/en/publications/publications/campaign-evaluation.pdf (Accessed 2 March 2016)

Gase, L.N., Barragan, N.C., Robles, B., Leighs, M. and Kuo, T. (2015). A mixed-methods evaluation of the choose less, weigh less portion size health marketing campaign in Los Angeles County. American Journal of Health Promotion, 29(6), e214-e224. DOI:10.4278/ajhp.131210-QUAN-623

Georgsson, M. and Staggers, N. (2016). An evaluation of patients' experienced usability of a diabetes mHealth system using a multi-method approach. Journal of Biomedical Informatics, 59, 115-129. DOI: 10.1016/j.jbi.2015.11.008

Greenspun, H. and Coughlin, S. (2012). mHealth in an mWorld: How mobile technology is transforming health care. Deloitte Center for Health Solutions. Available: http://www2.deloitte.com/content/dam/Deloitte/us/Documents/life-sciences-health-care/us-lhscmhealth-in-an-mworld-103014.pdf (Acessed 5 March 2016).

Hornik R. (2002). Public health communication: Making sense of contradictory evidence, in R.C. Hornik, ed., Public Health Communication: Evidence for Behavior Change (pp. 1-19). Mahwah, NJ: Erlbaum. 
Hornik, R. and Yanovitzky, I. (2003). Using theory to design evaluations of communication campaigns: The case of the National Youth Anti-Drug Media Campaign. Communication Theory, 13(2), pp. 204-224. DOI:10.1111/j.1468-2885.2003.tb00289

Ingelfinger, J.R., Kalantar-Zadeh, K., Schaefer, F. and World Kidney Day Steering Committee. (2016). World Kidney Day 2016: Averting the legacy of kidney disease - focus on childhood. Pediatric Nephrology, 31(3), pp. 343-348. DOI:10.1111/jorc.12148

Istepanian, R., Laxminarayan, S. and Pattichis, C.S. (2006). M-health: Emerging Mobile Systems. New York, NY: Springer Science+ Business Media, Incorporated.

Jha, V., Garcia-Garcia, G., Iseki, K., Li, Z., Naicker, S., Plattner, B., Saran, R., Wang, A.Y. and Yang, C.W. (2013). Chronic kidney disease: global dimension and perspectives. The Lancet, 382(9888), pp. 260-272.

Johnson, N., Hayes, L., Brown, K., Hoo, E. and Ethier, K. (2014). CDC National Health Report: Leading Causes of Morbidity and Mortality and Associated Behavioral Risk and Protective Factors-United States, 2005-2013. CDC, 63(04); pp. 3-27. Available: http://www.cdc.gov/mmwr/preview/mmwrhtml/su6304a2.htm (Acessed 6 February 2016).

Jurkovitz, C.T., Qiu, Y., Wang, C., Gilbertson, D.T. and Brown, W.W. (2008). The Kidney Early Evaluation Program (KEEP): Program design and demographic characteristics of the population. American Joumal of Kidney Diseases, 51(4), S3-S12.

Kay, M., Santos, J. and Takane, M. (2011). mHealth: New horizons for health through mobile technologies. World Health Organization, Global Observatory for e-Health, 64(7), pp. 66-71. Available from: http://www.who.int/goe/publications/goe_mhealth_web.pdf (Acessed 5 March 2016).

Khalil, A.A., Al-Modallal, H.M., Abdalrahim, M.S., Arabiat, D.H., Abed, M.A. and Zeilani, R.S. (2014). Development and psychometric evaluation of the Chronic Kidney Disease Screening Index. Renal failure, 36(8), pp. 1200-1207.

Korda, H. and Itani, Z. (2013). Harnessing social media for health promotion and behavior change. Health promotion practice, 14(1), pp. 15-23. DOI:10.1177/1524839911405850.

Koshy, S.M., Garcia-Garcia, G., Pamplona, J.S., Renoirte-Lopez, K., Perez-Cortes, G., Gutierrez, M.L., Hemmelgarn, B., Lloyd, A. and Tonelli, M. (2009). Screening for kidney disease in children on World Kidney Day in Jalisco, Mexico. Pediatric Nephrology, 24(6), pp. 1219-1225.

Lamb, B. (2010). Trusted guide to campaigning and influencing. National Council for Voluntary Organisations. Available at: http://therightethos.co.uk/files/NC636_Trustee_guide_to_campaigning_and_influencing.pdf. (Accessed 2 June 2016).

Levey, A.S., Coresh, J., Balk, E., Kausz, A.T., Levin, A., Steffes, Hogg, R., Perrone, R.D., Lau, J. and Eknoyan, G. (2003). National Kidney Foundation practice guidelines for chronic kidney disease: Evaluation, classification, and stratification. Annals of internal medicine, 139(2), pp. 137-147.

Mastroianni-Kirsztajn, G., Bastos, M.G. and Burdmann, E.A. (2010). Strategies of the Brazilian chronic kidney disease prevention campaign (2003-2009). Nephron Clinical Practice, 117(3), c259-c265. DOI:10.1159/000320741

Matias, N. and Sousa, M.J. (2016). Mobile health as a tool for behaviour change in chronic disease prevention: A systematic literature review. 11th Iberian Conference on Information Systems and Technologies (CISTI), Gran Canaria, 2016, pp. 1-6. DOI:10.1109/CISTI.2016.7521398

Miyamoto, S.W., Henderson, S., Young, H.M., Pande, A. and Han, J.J. (2016). Tracking health data is not enough: A qualitative exploration of the role of healthcare partnerships and mhealth technology to promote physical activity and to sustain behavior change. JMIR mhealth and uhealth, 4(1), e5. DOI: 10.2196/mhealth.4814

Nasri, H., Baradaran, A., Abedi-Gheshlaghi, Z. and Rafieian-Kopaei, M. (2015). World Kidney Day 2016: Awareness for Saving Kidneys. Shiraz E-Med J, 16(9, 10), e32273. DOI:10.17795/semj32273

National Center for Chronic Disease Prevention and Health Promotion (2009). The power of prevention. Chronic disease ... the public health challenge of the 21st century. Available: http://www.cdc.gov/chronicdisease/pdf/2009-Power-of-Prevention.pdf (Acessed 6 April 2016).

National Kidney Foundation (n.d.). Available at: https://www.kidney.org/kidneydisease (Accessed 28 June 2016).

Obrador, G.T., García-García, G., Villa, A.R., Rubilar, X., Olvera, N., Ferreira, Virgen, M., Gutiérrez-Padilla, J.A., Plascencia-Alonso, M., Mendoza-Garcia, M. and Plascencia-Pérez, S. (2010). Prevalence of chronic kidney disease in the Kidney Early Evaluation Program (KEEP) Mexico and comparison with KEEP US. Kidney International, 77, S2-S8.

Plantinga, L.C., Boulware, L.E., Coresh, J., Stevens, L.A., Miller, E.R., Saran, R., Messer, K.L., Levey, A.S. and Powe, N.R. (2008). Patient awareness of chronic kidney disease: trends and predictors. Archives of internal medicine, 168(20), pp. 2268-2275. DOI:10.1001/archinte.168.20.2268

Ramo, D.E., Thrul, J., Delucchi, K.L., Ling, P.M., Hall, S.M. and Prochaska, J.J. (2015). The Tobacco Status Project (TSP): Study protocol for a randomized controlled trial of a Facebook smoking cessation intervention for young adults. BMC Public Health, 15(1), pp. 1-9. DOI:10.1186/s12889-015-2217-0 
Redfern, J., Thiagalingam, A., Jan, S., Whittaker, R., Hackett, M.L., Mooney, Keizer, L., Hillis, J. S. \& Chow, C. K. (2014). Development of a set of mobile phone text messages designed for prevention of recurrent cardiovascular events. European journal of preventive cardiology,21(4), pp. $492-499$. DOI:10.1177/2047487312449416

Research and Markets (2015). mHealth: Game Changer for Healthcare. Available at: http://www.researchandmarkets.com/reports/3366162/mhealth-game-changer-for-healthcare (Accessed 25 February 2016)

Riekert, K., Ockene, J. and Pbert, L. (2013). The Handbook of Health Behavior Change, 4th Edition. Springer Publication.

Roomizadeh, P., Taheri, D., Abedini, A., Mortazavi, M., Larry, M., Mehdikhani, Mousavi, S.M., Hosseini, F.A., Parnia, A. and Nakhjavani, M. (2014). Limited knowledge of chronic kidney disease and its main risk factors among Iranian community: An appeal for promoting national public health education programs. International journal of health policy and management, 2(4), 161. DOI:10.15171/ijhpm.2014.37

Ryz, K., Tangri, N., Verrelli, M., Schneider, J., Lesyk, A., Eng, A., Hiebert, B., Whitlock, R.H., Sood, M.M., Rigatto, C. and Komenda, P. (2015). A before and after cross-sectional analysis of a public health campaign to increase kidney health awareness in a Canadian province. BMC research notes, 8(1), 695. DOI:10.1186/s13104-015-16622

Sallis, J.F., Owen, N. and Fisher, E.B, (2008). Ecological models of health behavior., In Glanz, B. K. Rimer, K. Viswanath, ed., Health behavior and health education: Theory, research, and practice (pp. 465-486). Jossey Bass: Wiley \& Sons, Inc.

Schiavo, R. (2013). Health communication: From theory to practice. John Wiley \& Sons.

Sixsmith, J., Doyle, P., D’Eath, M., Barry, M.M. (2014). Health communication and its role in the prevention and control of communicable diseases in Europe - Current evidence, practice and future developments. Available at: file:///D:/Desktop/health-communication-communicable-disease-europe.pdf (Accessed 16 March 2016).

SNS Research, Market Intelligence \& Consultancy Solutions (2014). The Mobile Healthcare (mHealth) Bible: 2015 - 2020. SNS Telecom.

The Economist Intelligence Unit Limited (2014). Value-based healthcare Strategies for medtech. A white paper from The Economist Intelligence Unit Healthcare. Available at: http://goingglobal.economist.com/en/2014/08/14/value-based-healthcare/ (Accessed 2 October 2016).

Tunstall-Pedoe, H. (2006). Preventing Chronic Diseases. A Vital Investment: WHO Global Report. Geneva: World Health Organization, 2005. pp 200. CHF 30.00. ISBN 924 1563001. Available at: http://www.who.int/chp/chronic_disease_report/en. International Journal of Epidemiology, 35(4), pp. $1107-1107$. (Accessed 16 March 2016).

Vassalotti, J.A., Li, S., McCullough, P.A. and Bakris, G.L. (2010). Kidney early evaluation program: a communitybased screening approach to address disparities in chronic kidney disease. In Seminars in nephrology, 30(1), pp. 6673. WB Saunders.

Vodopivec-Jamsek, V., de Jongh, T., Gurol-Urganci, I., Atun, R. and Car, J. (2012). Mobile phone messaging for preventive health care. The Cochrane Library. Cochrane Database of Systematic Reviews, issue 12, art. n.: CD007457. Published by John Wiley \& Sons, Ltd. DOI:10.1002/14651858.CD007457.pub2

West, D. (2012). How mobile devices are transforming healthcare. Issues in technology innovation, 18(1), pp. 1-11.

Wildevuur, S.E. and Simonse, S.E. (2015). Information and Communication Technology-Enabled PersonCentered Care for the "Big Five" Chronic Conditions: Scoping Review. Journal of Medical Internet Research, 17(3), e77. doi: 10.2196/jmir.3687

World Health Organization (2013). Global Action Plan for the Prevention and Control of Noncommunicable Diseases 2013-2020. Available at: http://apps.who.int/iris/bitstream/10665/94384/1/9789241506236_eng.pdf (Acessed 6 April 2016).

World Health Organization (2006). eHealth tools and services: Needs of the member states internet. Genève (Suisse): OMS. Available: http://apps.who.int/iris/bitstream/10665/69226/1/WHO_EHL_06.1_eng.pdf (Acessed 5 March 2016).

World Health Organization (2014). Global status report on noncommunicable diseases 2014. Available: http:/ /apps.who.int/iris/bitstream/10665/148114/1/9789241564854_eng.pdf (Acessed 5 March 2016). 


\section{APPENDICES}

\section{Appendix A}

Table 1.

\begin{tabular}{lll}
\hline $\begin{array}{l}\text { Authors, Year } \\
\text { and Country }\end{array}$ & $\begin{array}{l}\text { Campaign Goal/ } \\
\text { Sample/Length }\end{array}$ & $\begin{array}{l}\text { Campaign Type/ } \\
\text { Tools }\end{array}$ \\
\hline $\begin{array}{l}\text { Julie Ingelfinger } \\
\text { et al. (2016) }\end{array}$ & $\begin{array}{l}\text { Public Health Campaign } \\
\text { WKD 2016, focused on } \\
\text { childhood and the } \\
\text { antecedents of adult kidney } \\
\text { disease. }\end{array}$ & $\begin{array}{l}\text { Review/Reflection } \\
\text { Based on WHO } \\
\text { objectives to reduce } \\
\text { mortality from NCD } \\
\text { with a 10-year target } \\
\text { population level } \\
\text { initiatives. }\end{array}$ \\
& Campaign Length:1 year \\
& & $\begin{array}{l}\text { No references to the } \\
\text { use of technology to } \\
\text { reach or involve } \\
\text { participants. }\end{array}$
\end{tabular}

\begin{tabular}{ll}
\hline $\begin{array}{l}\text { Krista Ryz, et al. } \\
\text { (2015) - Canada }\end{array}$ & $\begin{array}{l}\text { Public Health Campaign } \\
\text { to Promote Kidney Health } \\
\text { through: }\end{array}$ \\
& (1) Increasing knowledge of \\
& CKD risk factors; \\
& (2) Promoting high-risk \\
& individuals for kidney \\
& function assessment. \\
& Sample: survey of 1606 adult \\
& participants (804 pre- and \\
& 802 posts). \\
& Campaign length: 2 \\
& months (in March) for two \\
& consecutive years (2010 and \\
& 2011).
\end{tabular}

\section{Guilhermo Gacia, Public Health Campaign et al. (2015) -} Mexico
No references to the - Not use of technology to evident reach or involve participants.
- Not - Overall awareness of the campaign messaging evident increased from $7 \%$ pre-campaign to $25 \%$ in the post campaign period. Ca. $2 / 3$ of respondents correctly identified a main theme message of the campaign;

- Awareness improved across most subgroups surveyed aside from those with lower education and income.

\section{Limitations:}

When comparing awareness and theme identification of subgroups among pre- and postintervention survey participants some numbers were too small to draw any firm conclusions. The evaluative process did not capture demographic data on ethnicity; Some of the increase in awareness may not translate into a change in behaviour. This is known as the knowledge gap and thus the true effect size on behaviour may be smaller than anticipated from the documented increase in awareness.

- A concerted attack against the diseases that lead to End Stage Renal Disease, by increasing community outreach, better education, improved economic opportunity and access to preventive medicine for those at highest risk, could end the unacceptable relationship between CKD and disadvantage in these communities.

- Initiatives such as the CKD hotspots and CKJ reviews series may help increase the awareness and facilitate the concerted efforts of health-care workers, epidemiologists, basic researchers and policy makers to decrease the burden of CKD.

\begin{tabular}{ll}
\hline $\begin{array}{l}\text { Hamid Nasri et } \\
\text { al. (2015) - Iran }\end{array}$ & Public Health Campaign \\
& World Kidney Day (WKD): \\
& focused on increased \\
& awareness of acute renal \\
& failure among hospital staff \\
& and physicians and the \\
& necessity for a public \\
& awareness campaign to make \\
& 'kidney attack' recognizable \\
& for the community. \\
& Campaign Length: 1 year \\
& (2013).
\end{tabular}

\section{Review/Reflection \\ - Not}

No references to the use of technology to reach or involve participants. evident - The general message of the WKD against an illness that leads to end-stage kidney failure, focused in better education, improved economic opportunity, increasing community outreach and access to protective medicine for individuals at highest risk, which could end the relationship between chronic renal failure and disadvantage populations.
Campaign Length: 1 year 


\begin{tabular}{llll}
\hline $\begin{array}{l}\text { Authors, Year } \\
\text { and Country }\end{array}$ & $\begin{array}{l}\text { Campaign Goal/ } \\
\text { Sample/Length }\end{array}$ & $\begin{array}{l}\text { Campaign Type/ } \\
\text { Tools }\end{array}$ & $\begin{array}{l}\text { Behaviour } \\
\text { Change } \\
\text { Evidence }\end{array}$ \\
$\begin{array}{llll}\text { Peyman } \\
\begin{array}{l}\text { Roomizadech et } \\
\text { al. (2014) - Iran }\end{array}\end{array}$ & $\begin{array}{l}\text { Public Health Campaign } \\
\text { World Kidney Day (WKD) }\end{array}$ & $\begin{array}{l}\text { Screening and } \\
\text { Mass Media } \\
\text { Campaigns }\end{array}$ & $\begin{array}{l}\text { - Not } \\
\text { evident }\end{array}$ \\
& Sample: 748 adult & - Radio & \\
& participants. & - Television \\
& Campaign Length: 1 year & - Printed materials & \\
& (2013). & - Bus & \\
& & - Web & \\
& & - Advertisements.
\end{tabular}

Conclusions

- The knowledge of Iranian population about

CKD and its risk factors is low;

- Future public health education programs should put efforts in community education;

- The high-risk individuals should receive tailored education and be encouraged to adopt lifestyle modifications to prevent or slow the progression of CKD.

Limitations:

- The methodology used for sample selection and data gathering. The respondents who participated in this survey were volunteers whose purpose was to participate in a kidney diseases awareness campaign. This may suggest that the respondents might be from a higher socio-economic status and had a higher level of education than the general Iranian population.

- In addition, the study did not include a question in the questionnaire as to whether or not the participating respondents with a CKD risk factor had a routine medical care or not. This omission should be considered in future surveys.

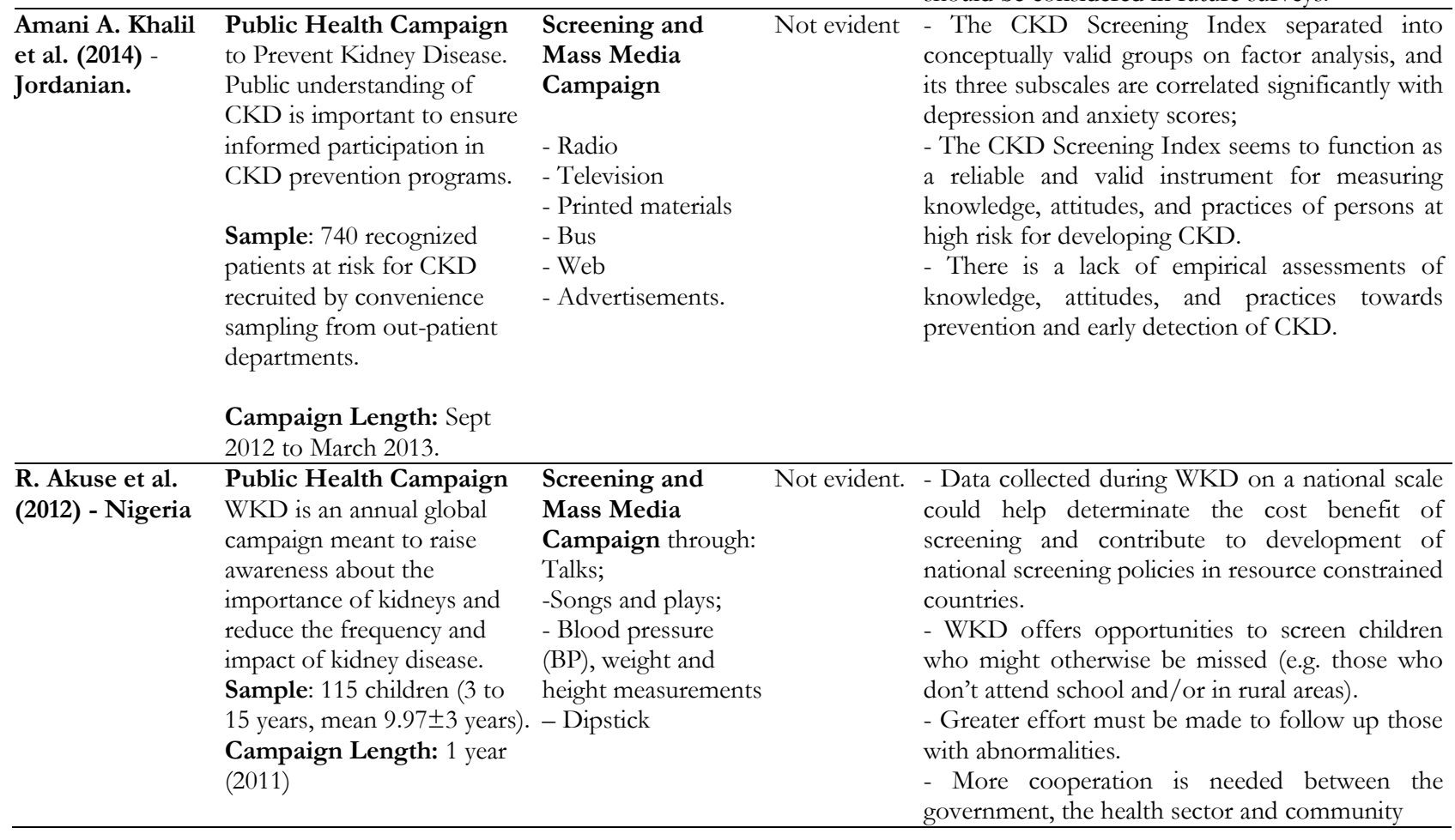


Journal of Information Systems Engineering \& Management, 2:1 (2017), 3

\begin{tabular}{|c|c|c|c|c|}
\hline $\begin{array}{l}\text { Authors, Year } \\
\text { and Country }\end{array}$ & $\begin{array}{l}\text { Campaign Goal/ } \\
\text { Sample/Length }\end{array}$ & $\begin{array}{l}\text { Campaign Type/ } \\
\text { Tools }\end{array}$ & $\begin{array}{l}\text { Behaviour } \\
\text { Change } \\
\text { Evidence }\end{array}$ & Conclusions \\
\hline $\begin{array}{l}\text { Altair Lima et al. } \\
\text { (2012) - Brazil }\end{array}$ & $\begin{array}{l}\text { Public Health Campaign: } \\
\text { Sample: } 38721 \text { inhabitants } \\
\text { screened and assisted by the } \\
\text { same main team of } \\
\text { professionals and volunteers } \\
\text { in different cities of the State } \\
\text { of Sao Paulo, in a total of } 123 \\
\text { health events Campaign } \\
\text { Length: } \\
\text { From Nov } 2005 \text { to Nov } 2010\end{array}$ & $\begin{array}{l}\text { Screening and } \\
\text { Mass Media } \\
\text { campaign: } \\
\text { Screening: Dipstick } \\
\text { test, blood pressure } \\
\text { measurement and } \\
\text { application of } \\
\text { medical } \\
\text { questionnaire. } \\
\text { Mass Media: } \\
\text { newspapers, radio, } \\
\text { web, TVs and } \\
\text { folders. }\end{array}$ & Not evident & $\begin{array}{l}\text { - Population-based studies have detected } 6-7 \% \text { of } \\
\text { albuminuria. The prevalence of CKD is higher } \\
(16 \%) \text { when those individuals at risk, including } \\
\text { relatives of patients with the disease, are screened; } \\
\text { - Mass population screening for CKD, with tests } \\
\text { such as urinalysis, is considered neither practical } \\
\text { nor likely to be successful or cost effective, } \\
\text { although it is valuable. In fact, most clinical } \\
\text { practice guidelines recommend identifying those at } \\
\text { risk. } \\
\text { - Evaluating individuals at risk is a priority versus } \\
\text { mass screening programmes, but this last approach } \\
\text { is also a way to reach 'awareness of population' and } \\
\text { authorities to the CKD as a public health problem. } \\
\text { - Prevention as an effective tool for controlling' } \\
\text { the increasing CKD incidence. } \\
\text { Limitation: Demographic information provided } \\
\text { by the study should be interpreted with caution, as } \\
\text { the subjects were involved in this survey as they } \\
\text { looked for information or assistance in a } \\
\text { prevention campaign and there was no kind of } \\
\text { randomization. }\end{array}$ \\
\hline $\begin{array}{l}\text { Joseph A. } \\
\text { Vassalotti, et al. } \\
\text { (2010) - EUA }\end{array}$ & $\begin{array}{l}\text { Public Health Program: } \\
\text { Kidney Early Evaluation } \\
\text { Program (KEEP) is a free, } \\
\text { community-based, kidney } \\
\text { disease-screening program to } \\
\text { detect chronic kidney disease } \\
\text { (CKD) This program screens } \\
\text { individuals with diabetes, } \\
\text { hypertension, or those with a } \\
\text { first-degree relative with } \\
\text { diabetes, hypertension, } \\
\text { and/or kidney disease. } \\
\text { Sample: } 89,552 \text { participants } \\
\text { (excludes individuals younger } \\
\text { than } 18 \text { years of age and } \\
\text { those treated with dialysis or } \\
\text { kidney transplantation.) } \\
\text { Campaign length: August } \\
\text { 2000 to December 2007. }\end{array}$ & $\begin{array}{l}\text { Screening and } \\
\text { Detection } \\
\text { Campaign: } \\
\text { - screening centers } \\
\text { - pre-screening } \\
\text { campaigns using } \\
\text { brochures, posters, } \\
\text { and media public } \\
\text { service } \\
\text { announcements. }\end{array}$ & Not evident & $\begin{array}{l}\text { - The program shows the ability to reach racial, } \\
\text { ethnic and vulnerable populations; } \\
\text { - The community engagement of KEEP also has } \\
\text { the potential advantage of the ripple effect to } \\
\text { educate the community at large about CKD risk } \\
\text { factors in addition to the individuals screened. } \\
\text { - Preliminary data suggest that for African } \\
\text { Americans KEEP is more likely to increase } \\
\text { awareness of hypertension and diabetes as well as } \\
\text { engage individuals to follow up with clinicians for } \\
\text { treatment of risk conditions. } \\
\text { Limitations: } \\
\text { A limitation is the assessment of diabetes control } \\
\text { on the KEEP cohort was the use of fasting or non- } \\
\text { fasting glucose. A better reflection of glycaemic } \\
\text { control over time would be haemoglobin. }\end{array}$ \\
\hline $\begin{array}{l}\text { Gianna Mastroia } \\
\text { nni-Kirsztajn, et } \\
\text { al. (2010) - Brazil }\end{array}$ & $\begin{array}{l}\text { Public Health Campaign: } \\
\text { WKD Campaign to prevent } \\
\text { kidney disease. } \\
\text { Aims to alert the population, } \\
\text { health professionals and } \\
\text { authorities to this risk. } \\
\text { Sample: Population in } \\
\text { general. (how many } \\
\text { participants??) } \\
\text { Campaign Length: } 2003 \text { - } \\
2009\end{array}$ & $\begin{array}{l}\text { Screening and } \\
\text { Mass Media } \\
\text { Campaign: } \\
\text { Population } \\
\text { screening, media } \\
\text { communication, } \\
\text { events and meetings, } \\
\text { distribution of } \\
\text { educational materials } \\
\text { (t-shirts, booklets), } \\
\text { routine report of } \\
\text { estimated glomerular } \\
\text { filtration rate), } \\
\text { practice sharing } \\
\text { among professionals } \\
\text { and public in general } \\
\text { (talks). }\end{array}$ & $\begin{array}{l}\text { Not } \\
\text { sufficient to } \\
\text { educate or } \\
\text { for } \\
\text { behaviour } \\
\text { change } \\
\text { evidence }\end{array}$ & $\begin{array}{l}\text { - The program decrease un-awareness regarding } \\
\text { CKD in Brazil and was saw as first step on the long } \\
\text { way to reach an effective prevention of this } \\
\text { disease; } \\
\text { - Media channels were used to alert people but it } \\
\text { was not sufficient to effectively educate public. }\end{array}$ \\
\hline
\end{tabular}




\begin{tabular}{|c|c|c|c|c|}
\hline $\begin{array}{l}\text { Authors, Year } \\
\text { and Country }\end{array}$ & $\begin{array}{l}\text { Campaign Goal/ } \\
\text { Sample/Length }\end{array}$ & $\begin{array}{l}\text { Campaign Type/ } \\
\text { Tools }\end{array}$ & $\begin{array}{l}\text { Behaviour } \\
\text { Change } \\
\text { Evidence }\end{array}$ & Conclusions \\
\hline $\begin{array}{l}\text { Gregorio T. } \\
\text { Obrador et al. } \\
\text { (2010) - Mexico } \\
\text { \& USA }\end{array}$ & $\begin{array}{l}\text { Public Health Program: } \\
\text { The National Foundation } \\
\text { Kidney Early Evaluation } \\
\text { Program (KEEP) is a free } \\
\text { community-screening } \\
\text { program aimed at early } \\
\text { detection of kidney disease } \\
\text { among high-risk individuals. } \\
\text { Sample: } 1519 \text { participants } \\
\text { from general population in } \\
11 \text { screenings. } \\
\text { Campaign Length: Pilot } \\
\text { starts in Mexico in sept } 2008 \\
\text { to june } 2009 \text { in two cities. }\end{array}$ & $\begin{array}{l}\text { Screening and } \\
\text { Mass Media } \\
\text { Campaigns: } \\
\text { diabetes, } \\
\text { hypertension and } \\
\text { family diseases } \\
\text { screening, center } \\
\text { diagnoses, surveys, } \\
\text { advertisement. }\end{array}$ & $\begin{array}{l}\text { Comparison } \\
\text { of studies } \\
\text { KEEP } \\
\text { Mexico pilot } \\
\text { phase, } \\
\text { KEEP USA } \\
\text { and National } \\
\text { Health } \\
\text { Surveys } \\
\text { (ENSA 2000 } \\
\text { and } \\
\text { NHANES } \\
\text { 1999-2006) }\end{array}$ & $\begin{array}{l}\text { - CKD is highly prevalent under diagnosed, and } \\
\text { under recognized among high-risk individuals in } \\
\text { Mexico. } \\
\text { - KEEP is an effective screening program that can } \\
\text { successfully be adapted for use in Mexico. } \\
\text { - For } 52 \% \text { of KEEP Mexico City participants, } \\
\text { family history of diabetes, hypertension, or CKD } \\
\text { was the only screening program entry criteria that } \\
\text { they met. } \\
\text { - Hypercholesterolemia prevalence was lower in } \\
\text { KEEP Mexico City than in KEEP Jalisco or } \\
\text { KEEP US, and current smoking was less prevalent } \\
\text { in KEEP Mexico than in KEEP US. }\end{array}$ \\
\hline $\begin{array}{l}\text { Ho Jun Chin et } \\
\text { al. (2010) - Korea }\end{array}$ & $\begin{array}{l}\text { Public Health Campaign: } \\
\text { WKD Campaign to prevent } \\
\text { CKD. } \\
\text { Trends in CKD awareness } \\
\text { described before and after } \\
\text { the WKD campaign and its } \\
\text { impact in increasing } \\
\text { awareness and appropriate } \\
\text { management of the risk } \\
\text { factors for cardiovascular } \\
\text { disease and renal progression. } \\
\text { Sample: Population in } \\
\text { general (57 } 718 \text { people who } \\
\text { had undergone a routine } \\
\text { health check-up). } \\
\text { Campaign Length: Nov } \\
\text { 2006 to March } 2007\end{array}$ & $\begin{array}{l}\text { Screening and } \\
\text { Mass Media } \\
\text { Campaign: Lectures } \\
\text { in Hospitals and free } \\
\text { medical examinations } \\
\text { Mass Media } \\
\text { campaign through } \\
\text { nationwide television } \\
\text { broadcasts, local } \\
\text { television, radios, } \\
\text { newspapers and } \\
\text { internet. Mass media } \\
\text { coverage on } \\
\text { behavioural change } \\
\text { in relation to } \\
\text { screening, medicine } \\
\text { taking and treatment. }\end{array}$ & $\begin{array}{l}\text { Positive } \\
\text { impact on } \\
\text { the } \\
\text { awareness } \\
\text { and control } \\
\text { of risk } \\
\text { factors in } \\
\text { CKD }\end{array}$ & $\begin{array}{l}\text { - The WKD campaign had a positive impact on } \\
\text { the awareness and control of risk factors in CKD } \\
\text { subjects but the absolute frequency of CKD } \\
\text { awareness still remains undesirable in Korea; - } \\
\text { There are needed new campaign strategies to } \\
\text { publicize the importance of early diagnosis and } \\
\text { appropriate management of CKD; - CKD } \\
\text { awareness was increased after the WKD campaign } \\
\text { in Korea, especially in stage } 2 \text {, } 3 \text { and } 4 \text { CKD } \\
\text { subjects.; } \\
\text { - CKD awareness was related to higher awareness } \\
\text { of HTN and DM in CKD; - Although the WKD } \\
\text { campaign had a positive impact on the awareness } \\
\text { and control of risk factors in CKD subjects, the } \\
\text { absolute frequencies of the awareness and control } \\
\text { of risk factors for renal progression and } \\
\text { cardiovascular events remained undesirable. } \\
\text { Limitations: (1) The questionnaire item assessing } \\
\text { awareness may be misinterpreted by the } \\
\text { participants (2) Miss classification of disease. (3) } \\
\text { The sample was not taken from general } \\
\text { population, but only from the ones who were } \\
\text { under check-up- }\end{array}$ \\
\hline $\begin{array}{l}\text { Claudine T. } \\
\text { Jurkovitz et al. } \\
\text { (2008) - EUA }\end{array}$ & $\begin{array}{l}\text { Public Health Program: } \\
\text { Kidney Early Evaluation } \\
\text { Program (KEEP), from the } \\
\text { National Kidney Foundation, } \\
\text { initiated in 2000, offering } \\
\text { surveillance and early } \\
\text { detection of CKD. } \\
\text { Sample: Adults with a family } \\
\text { history of kidney disease or } \\
\text { personal or family history of } \\
\text { diabetes or hypertension. } \\
\text { Since } 2000 \text {, the number of } \\
\text { enrolled participants has } \\
\text { grown exponentially from } \\
\text { 6,082 to } 73,460 \text { in } 2006 \text {. } \\
\text { Campaign Length: } 2000 \text { - } \\
\text { 2006 }\end{array}$ & $\begin{array}{l}\text { Screening and } \\
\text { detection } \\
\text { campaign: } \\
\text { - screening centers } \\
\text { - pre-screening } \\
\text { campaigns to } \\
\text { promote attendance } \\
\text { using brochures, } \\
\text { posters, and media } \\
\text { public service } \\
\text { announcements. } \\
\text { - }\end{array}$ & $\begin{array}{l}\text { Successful in } \\
\text { enrolling } \\
\text { individuals at } \\
\text { risk of } \\
\text { kidney } \\
\text { disease }\end{array}$ & $\begin{array}{l}\text { Conclusions: KEEP has been successful in } \\
\text { enrolling individuals at risk of kidney disease, } \\
\text { evidenced by the high levels of self-reported } \\
\text { hypertension and diabetes. }\end{array}$ \\
\hline
\end{tabular}


Journal of Information Systems Engineering \& Management, 2:1 (2017), 3

\begin{tabular}{|c|c|c|c|c|}
\hline $\begin{array}{l}\text { Authors, Year } \\
\text { and Country }\end{array}$ & $\begin{array}{l}\text { Campaign Goal/ } \\
\text { Sample/Length }\end{array}$ & $\begin{array}{l}\text { Campaign Type/ } \\
\text { Tools }\end{array}$ & $\begin{array}{l}\text { Behaviour } \\
\text { Change } \\
\text { Evidence }\end{array}$ & Conclusions \\
\hline $\begin{array}{l}\text { Laura C. } \\
\text { Plantinga et al. } \\
(2008) \text { - EUA }\end{array}$ & $\begin{array}{l}\text { Public Health Campaign: } \\
\text { National awareness } \\
\text { intervention in CKD } \\
\text { Sample: Awareness rates } \\
\text { were assessed in } 2992 \text { adults } \\
\text { ( } \geq 20 \text { years) with CKD stages } \\
\text { 1-4 from a nationally } \\
\text { representative. } \\
\text { Campaign Length: } \\
\text { Data from the 1999-2000, } \\
\text { 2001-2002, and 2003-2004 } \\
\text { (9) NHANES surveys. }\end{array}$ & $\begin{array}{l}\text { National Survey to } \\
\text { evaluate awareness, } \\
\text { using questionnaires, } \\
\text { interviews and } \\
\text { physical exams. }\end{array}$ & Not Evident & $\begin{array}{l}\text { - Disease awareness among U.S. adults with CKD, } \\
\text { as defined by KDOQI staging (3), was generally } \\
\text { quite low. Even at CKD stage 4, fewer than half of } \\
\text { the persons with CKD were aware of their disease; } \\
\text { - Further efforts to enhance the patient-provider } \\
\text { relationship, in the context of discussion of CKD, } \\
\text { may improve awareness; } \\
\text { - Lifestyle factors, such as obesity, physical activity, } \\
\text { smoking, and alcohol use were not associated with } \\
\text { CKD awareness; } \\
\text { - Future studies of disease awareness among those } \\
\text { with CKD should focus on intervention by } \\
\text { examining patient, provider, and societal (e.g., } \\
\text { public relations campaigns) factors that lead to } \\
\text { better CKD awareness. }\end{array}$ \\
\hline
\end{tabular}

